\title{
Review
}

\section{Kierkegaard and the matter of philosophy: A fractured dialectic}

\author{
Michael O’Neill Burns \\ Rowman \& Littlefield, London, 2015, xxii+202 pp., \\ ISBN: 978-1-78348-203-0
}

Contemporary Political Theory (2017) 16, 317-320. doi:10.1057/s41296-016-0018-6; advance online publication 8 August 2016

Kierkegaard's contribution to political theory remains an unsolved puzzle. Whereas some read him as an apologist for Denmark's old monarchy, others see him as apolitical, or, if that is too naïve, as the most political thinker ever - a view ordained by no one other than Carl Schmitt, who referenced Kierkegaard's "exception" as the true model of sovereignty. Absent from these readings is an engagement with the complex interweaving of self and other, thinking and action, that runs through most of Kierkegaard's writings. Only a few of Kierkegaard's interlocutors have tried to work out his account of repetition and its implications for non-sovereign agency. Similarly, we find little interest in his rethinking of the public, which displaces the binary between atomism and holism and instead nourishes an experience of becoming and singularity situated within a network of contested intersubjective relations. The lack of attention to these issues is striking given Kierkegaard's own practice of reading and interpretation. What the last fifty years of Kierkegaard scholarship demonstrates is not only a dubious practice of intellectual cherry-picking; worse still, the debates unveil a failure to pursue the same kind of curiosity and inventiveness that we so commonly associate with Kierkegaard himself.

Michael O'Neill Burns' new book Kierkegaard and the Matter of Philosophy goes a long way to overcome this sad state of affairs. (Despite no reference to politics in the title, the book is the first in a new series by Rowman \& Littlefield that "aims to mine the rich resources of philosophers in the 'continental' tradition to thinking the political.") The main wager is that the path to Kierkegaard's political theory goes through a systematic reconstruction of his ontological assumptions concerning subjectivity and sociability - what Burns calls "political ontology" (p. 118). Burns explicates this ontology by reorienting Kierkegaard's place in the philosophical tradition, aligning him closer to German Idealism than most other interpreters have done. Through a series of close and elegantly construed readings,

(c) 2016 Macmillan Publishers Ltd. 1470-8914 Contemporary Political Theory Vol. 16, 2, 317-320 www.palgrave.com/journals 
Burns shows that Kierkegaard, in texts such as The Concept of Anxiety, responds directly to Hegel, Fichte, and Schelling in order to develop an ontology based on the negation of any firm ground (p. 37). The point is not to suggest that Kierkegaard is a German idealist, but rather to show how he draws on this tradition by turning it against itself. Burns secures this point by arguing that Kierkegaard's philosophy amounts to a non-theological "fractured dialectics": "a non-totalizable account of dialectical structure that does not emerge from, or arrive at, a synthetic unity of opposites" (p. 61).

Conjoined with this argument is the suggestion that we read Kierkegaard as the proponent of a "transcendental materialism," which in turn prefigures insights in recent works by Alain Badiou, Catherine Malabou, and Slavoj Žižek (p. xvii). To claim that Kierkegaard is a materialist is surely startling, especially given the link to German idealism. But the suggestion seems to follow directly from the emphasis on fractured dialectics: if we think that no idea can ever capture everything there is, and if we accept that ideational structures are reflections of the material world, then we might also be inclined to say that human thought is a product of the contradictions contained in matter itself. Burns develops this argument through a reading of Kierkegaard's concept of actuality (esp. pp. 35-38). According to this reading, actuality is an existential rather than logical category, which highlights the contingent and finite dimension of all modes of reflection, including philosophy. Any attempt at thinking the world - and thus any attempt at making the world appear in actuality - is always-already preceded by an absolute beginning that exceeds our attempt at comprehending it. The excess explains why anxiety has ontological significance for Kierkegaard. It un-grounds subjectivity, turning it into a mode of becoming fraught with blind spots and unanticipated possibilities.

While Burns is careful not to suggest that Kierkegaard's writings imply a hidden argument about how to govern society, he does draw on these philosophical insights in order to explicate the elements of a political theory that would capture something decisively Kierkegaardian. The kernel of his argument is a conception of freedom that operates in the space between "meaninglessness and possibility" (p. 50) - that is, in between the unground of any actual instantiation of the subject and the infinite range of possibilities opened up by this unground. Burns links this conception to Kierkegaard's critique of his own age ("the present age") and the subsequent call for a radical transformation driven by an enthusiastic passion for life ("the revolutionary age"). The aim of such a transformation is neither the breakdown of society nor a "synthesis between the self and the other" (p. 129), but rather the development of a society in which individuals take up the fractured dialectics by collectively affirming the ideal of singularity: "individuals become related to others who are also passionately related to the same idea" (p. 129). In this formulation, we find a solution to the problem that haunts much of so-called continental political theory (which in this context includes Badiou and Žižek). How is it possible to bridge between a formal account of a radical political subjectivity 
and the lived experiences embodying this account? The answer, Burns argues, follows from Kierkegaard's suggestion that we, as a collective resisting unification, invest ourselves passionately in the idea of singularity (p. 174).

As already indicated, there is much to appreciate about this argument, and any objections to the book must be measured against the dearth of scholarship on Kierkegaard's many provocative contributions to contemporary political theory. Still, despite Burns' commitment to a systematic account of Kierkegaard's political ontology, it is not evident that the book unearths the full potential of his writings. An important reason for this is Burns' insistence on locating Kierkegaard within the German idealist tradition and the subsequent turn to transcendental materialism. It is not the turn to materialism as such that stands out in this context; rather, the cause for concern follows from the designation transcendental. This designation would surely miff Kierkegaard, in part because it assumes the kind of systematicity that he sought to resist throughout his own writings. Moreover, the designation downplays Kierkegaard's ongoing interest in the myriad of passions and their divergent modes of embodiment, in particular in works such as Either/Or and Concluding Unscientific Postscript. Foregrounding these works may align Kierkegaard's materialism with Spinozism rather than German idealism, but this should not surprise, since Spinoza too was an important source of inspiration for thinkers such as Schelling and Fichte, a point that remains largely overlooked in the transcendental reading of Kierkegaard.

To see why such a repositioning matters, consider Burns' argument that, for Kierkegaard, politics is about a collective and passionate investment in the idea of singularity. Burns is curiously silent on what this means and how it might come about. What kinds of passions empower an investment in singularity? Do the passions differ across time and place? Do they imply particular modes of mediation? The point of these questions is not to ask for a political blueprint of some kind. What they instead demand is a degree of specificity that will give us some traction on the politics of passion and singularity. A transcendental materialist reading of Kierkegaard is limited in this regard, not only because it posits an abstract conception of passion, but also because it turns our attention away from the multiple ways in which Kierkegaard sought to traverse the usual distinctions between the one and the many, the free and the unfree. The experimentation embedded in this is neither authoritarian (à la Schmitt) nor absolutist (à la Žižek and Badiou), but instead it suggests a political orientation that, in the name of singularity, affirms the incongruous and the incomplete. Burns is right to suggest that this affirmation sometimes belongs to a register of angst and anxiety. But as many of Kierkegaard's writings also express so eloquently, it is more likely to develop in a comic register that mediates between the absence of ground and the excitement (even elation) produced by the realization that another world is possible.

(C) 2016 Macmillan Publishers Ltd. 1470-8914 Contemporary Political Theory Vol. 16, 2, 317-320 
If we want to appreciate Kierkegaard's contribution to contemporary political theory, it is imperative that we appreciate and further develop this aspect of his writings. Notwithstanding its limitations, Burns' book is an important step in this direction.

Lars Tønder

University of Copenhagen, 1014 Copenhagen K, Denmark lt@ifs.ku.dk 